\title{
Antibacterial activity of Muntingia calabura Lam. Against Some Selected Bacteria Causing Mastistis
}

\author{
Puguh Surjowardojo*, Imam Thohari, Firmansyah Tri Syahputra, Aswah Ridhowi \\ Faculty of Animal Husbandry, University of Brawijaya, Indonesia \\ Jl. Veteran Malang, East Java, Indonesia. 65145 \\ puguh.surjowardojo@gmail.com
}

\begin{abstract}
The use of herbal plants are widely knows to be used in the treatment of various infectious diseases throughout the history of mankind. The aim of this study was to determine the effectiveness of extract Muntingia calabura $L$ at different storage (refrigerator vs. room temperature) and time duration $(0,2,4,6,8$ days) againts Staphylococcus aureus and Streptococcus agalactiae for the antibacterial activity. The activity was analyzed using paper disc diffusion method. The study revealed that extracts Muntingia calabura $L$ in different storage and duration time inhibited growth of the test bacteria to varying degrees $(\mathrm{P}<0.05)$. Muntingia calabura $L$ stored at refrigerator temperature gives higher diameter zone of inhibition than room temperature $(\mathrm{P}<0.05)$. On $\mathrm{S}$. aureus bacteria, the diameter of inhibition zone produced at refrigerator temperature and room temperature with storage time $0,2,4,6$ and 8 days were $(22.46 \mathrm{~mm}$ vs. $21.41 \mathrm{~mm}) ;(20.26 \mathrm{~mm}$ vs. $18.86 \mathrm{~mm}) ;(18.44 \mathrm{~mm}$ vs. $15.42 \mathrm{~mm}) ;(16.21 \mathrm{~mm}$ vs. $10.46 \mathrm{~mm}) ;(13.46 \mathrm{~mm}$ vs. $6.68 \mathrm{~mm})$ respectively. While, on S. agalactiae bacteria were $(18.28 \mathrm{~mm}$ vs. $17.22 \mathrm{~mm}) ;(14: 45 \mathrm{~mm}$ vs. $16.72 \mathrm{~mm}) ;(14.22 \mathrm{~mm}$ vs. $11.56 \mathrm{~mm})$; $(12.48 \mathrm{~mm}$ vs. $8.83 \mathrm{~mm}) ;(11.34 \mathrm{~mm}$ vs. $5.24 \mathrm{~mm})$. From these results it appears that, Muntingia calabura $L$ stored at refrigerator temperature for 0 days provide better results in inhibiting the activity of bacteria that cause mastitis.
\end{abstract}

Keywords: Muntingia calabura L., mastitis, Staphylococcus, Streptococcus

\section{INTRODUCTION}

Staphylococcus aureus and Streptococcus agalactiae have been reported as the most common bacterial agent of mastitis (Khan et al., 2003). This organism primarily infects the cisterns and the ductal system of the mammary gland. An irritant is produced, causing inflammation of the gland which is mostly subclinical with occasional clinical symptoms. Accumulation of bacteria waste products intensifies the inflammatory response resulting in destruction of milk producing tissues and reduced milk yield (Myllys et. al., 1995).

The use of herbal plants are widely knows to be used in the treatment of various infectious diseases throughout the history of mankind. Plant materials continue to provide the major source of natural therapeutic remedies and play an important role in health care in many developing country (Ody, 1993). Higher plants, which are able to produce photosynthesis, produce hundreds to thousands of diverse chemical compounds with different biological activities (Hamburger and Hostettmann, 1991). It is believed that these compounds have an important ecological role. They can work as pollinator attractants and as chemical defenses against insects, herbivores and microorganisms (Harborne, 1990). These antimicrobial compounds produced by plants are active against plant and human pathogenic microorganisms (Sarac and Ugur, 2007). There are several reports in the literature regarding 
the antimicrobial activity of plant crude extracts and the bioassay-guided fractionation of those extracts that yielded active principles (Rabe and Van Staden, 2000; Palombo and Semple, 2001; Portillo et al., 2001)

Muntingia calabura is widely cultivated and has become one of the common roadside trees in Indonesia. It is known locally in Indonesia as 'Kersen. It is native to the American continent and is widely cultivated in warm areas of Asian region (Chin, 1989). Various parts of this tree have several documented medicinal uses in both Southeast Asia and tropical America (Kaneda et al., 1991; Nshimo et al., 1993). The roots have been employed as an emmenogogue in Vietnam and as an abortifacient in Malaysia. In the Philippines, the flowers of this species have been used to treat headaches, and as an antidyspeptic, antispasmodic and diaphoretic. Infusions of the flowers of this plant are drunk as a tranquillizer and tonic in Colombia (Kaneda et al., 1991). Therefore, the main objective of this study is investigate the possible antibacterial activity extracts of Muntingia calabura against Staphylococcus aureus and Streptococcus agalactiae bacteria at different stored method and long shelf life using invitro dics diffusion method to reduce mastitis

\section{MATERIAL AND METHOD}

\section{Collection of plant}

Fresh plant leaves of Muntingia calabura were collected from Ngantang Subdistrict, Malang Regency, East Java Province, Indonesia. The leaves was cleaned thoroughly with normal tap water followed by sterile distilled water. The leaves were dried under shaded condition at room temperature, then the leaves were dried in an oven at $60^{\circ} \mathrm{C}$ for $24 \mathrm{hrs}$. Leaves were crushed to powder using grinding machine. Powder were storage at $4^{\circ} \mathrm{C}$ in sealed bottle.

\section{Extraction}

All extraction was carry out in the ratio 1:5 (w/v) for $24 \mathrm{~h}$ by using maseration method extraction. The residues of extraction from from different method and time storage further evaporated by using rotary evaporator at $60^{\circ} \mathrm{C}$. The concentration of extration to determine inhibiting zone in each solvent were $40 \%$. Theconcentration were dissolved with its own solvent. Twenty micro liter of respective extract were then loaded in to empty sterile blank disck $(5 \mathrm{~mm})$ and left it dry to the room temperature under sterilized condition prior

\section{Preparation of Microorganism Culture}

The bacteria ware taken from fresh milk with CMT score 3. Identification of Staphylococcus aureus and Streptococcus agalactiae was conducted using MSA and MRSA. The abovementioned bacteria were incubated at $37^{\circ} \mathrm{C}$ for $24 \mathrm{~h}$ after injection into nutrient borth., sterilized in a flask and cooled to $40-50^{\circ} \mathrm{C}$ was poured, in the volume of Fifteen microliter, into sterilized petri dishes (diameter of $5 \mathrm{~mm}$ ) and allowed to harden under room temperature. This is followed by homogenous distribution of $0.1 \mathrm{~mL}$ bacteria culture $\left(10^{7}\right.$ bacteria per $\mathrm{mL}$ ) onto medium of petridishes. Dishes loaded with extracts were then positioned on the solid agar medium by pressing slightly. Petridishes were palced in incubator according to their respective growth temperature and condition for 18 to $24 \mathrm{~h}$. At 
the end of the period, nhibiting zones formed was measured in $\mathrm{mm}$. The study was performed in triplicate and the formation of the inhibiting zones were compare with control (iodip).

\section{Results and Discussion}

Inhibitiing zone of $M$. calabura stored at different methods and lengths of time on the activities of the bacteria $S$ aureus and $S$ agalactiae showed various results as shown in Table 1 below.

Table 1. Inhition zone of Muntingia calabura at different method stored and long shelf life against $S$. aureous and $S$. agalactiae

\begin{tabular}{ccccc}
\hline long shelf life & \multicolumn{2}{c}{ Room temperature stored } & \multicolumn{2}{c}{ Refrigerator stored } \\
\cline { 2 - 5 } & Saureous & Sagalactiae & Saureous & Sagalactiae \\
\hline Day to 0 & $21.41^{\mathrm{a}}$ & $17.22^{\mathrm{a}}$ & $22.46^{\mathrm{a}}$ & $18.28^{\mathrm{a}}$ \\
Day to 2 & $18.86^{\mathrm{b}}$ & $14.45^{\mathrm{b}}$ & $20.26^{\mathrm{b}}$ & $16.72^{\mathrm{b}}$ \\
Day to 4 & $15.42^{\mathrm{c}}$ & $11.56^{\mathrm{c}}$ & $18.44^{\mathrm{c}}$ & $14.22^{\mathrm{c}}$ \\
Day to 6 & $10.46^{\mathrm{d}}$ & $8.83^{\mathrm{d}}$ & $16.21^{\mathrm{d}}$ & $12.48^{\mathrm{d}}$ \\
Day to 8 & $6.68^{\mathrm{e}}$ & $5.24^{\mathrm{e}}$ & $13.46^{\mathrm{e}}$ & $11.34^{\mathrm{e}}$ \\
\hline
\end{tabular}

$* \mathrm{P}<0.05$

Results in Table 1provide information that $M$. calabura have the ability to inhibit the activity of the bacteria $S$ aureus and $S$ agalactiae by the appearance of clear zone on an agar medium diameter which was measured by a caliper. $M$. calabura extract has the highest level of effectiveness in day- 0 then continued to decline until the day- 8 . On the day- 0 inhibition produced at room temperature storage againts $S$. aureus and $S$. agalactiae were $21.41 \mathrm{~mm}$ and $17.22 \mathrm{~mm}$, while the stored at refrigerator temperature, giving higher yields againts two types of bacteria were $22.41 \mathrm{~mm}$ and $1822 \mathrm{~mm}$ respectively. M. calabura extract stored at refrigerator temperature provides better results in inhibiting the activity of bacteria that cause mastitis. It is expected as a result of contamination least obtained. In addition, the cooler temperature allegedly will inhibiting the activity breakdown extract for bacterial activity. The type of bacteria also affecting inhibition mechanism of bacteria. Seen from the resulting inhibition against $S$. aureus bacteria is greater than the $S$. agalactiae, so it can be said that $S$ aureus easier to inhibited activity compared with the $S$ agalactiae. This is supported by the opinion of Palombo and Sampe (2001) which explains that the gram-positive and gramnegative have a different sensitivity to antibacterial agents due to differences in cell wall structure such as the amount of peptidoglycan, which determines the amount of lipid penetration, binding and antibacterial activity.

The ability of $M$. calabura to inhibit the growth of $S$ aureus and $S$ agalactiae is the result of the activity of antibacterial compounds contained in $M$. calabura leaves like flavoniod, saponins and tannins (Noorhamdani et al., 2012). Zakaria et al, (2007) reported that qualitatively, flavonoids are the most dominant on the leaves of M. calabura that may cause damage to the permeability of the cell wall and can cause lysis of the cells. Furthermore, saponin serves to lower the surface tension of the cell wall. Nikham and Basjir (2012) adds that when interactions occur continuously in the cell wall of the bacteria can cause cell wall rupture or lysis. The walls of bacteria that has lysis due to flavonoids and 
saponins cause tannin can easily enter and coangulate $S$ aureus cell protoplasm so that the cell can not perform activities of life and stunted or even die.

\section{CONCLUSION}

Based on the results of this study concluded that:

1. The longer shelf life M. calabura extract, the ability of inhibition of bacteria will be lower. The greatest inhibition produced on day- 0 , and then continued to decline until the day -8 .

2. M.Calabura stored at refrigerator temperatures produce higher inhibition zone compare stored at room temperature.

3. The diameter of inhibition zone against $S$ aureus produces a value that is higher than the inhibition zone of $S$ agalactiae. This indicates that the $S$ aureus easier to inhibited activity compared with $S$ agalactiae. Allegedly as a result of differences in the structure of the bacteria walls.

\section{REFERENCE}

Chatha, S.A.S., F. Anwar, M. Manzoor, and J. R. Bajwa. 2006.Evaluation of the antioxidant activity of rice bran extracts using different antioxidant assays. Gracass Aceites Selvina. 57: $328-335$.

Chin W.Y. 1989. A Guide to The Wayside Trees of Singapore. BP Singapore Science Centre p. 145

Dionex. 2001. Sensitive Determination of Catechins in Tea by HPLC. Thermo scientific. 275.

Hamburger M and K. Hostettmann. 1991. Bioactivity in Plants: The Link Between Phytochemistry and Medicine. Phytochem. 30: 3804-3814.

Harbone, B. 1998. Phytochemical Methods: A Guide to Modern Techniques of Plant Analysis. Chapman and Hall Co. New York.

Kaneda N., J.M. Pezzuto, D.D. Soejarto, A.D. Kinghorn, N.R. Farnwort, T. Santisuk, P. Tuchinda, J. Udchachon and V. Reutrakul. 1991. Plant Anticancer Agents, XLVII. New Cytotoxic Flavanoids from Muntingia calabura Roots. J. Nat. Prod. 54: 196-206.

Khan, I.U., A.A. Hassan, A. Abdulmawjood. C. Lanimler, W. Wolter, and M. Zschock. (2003); Identification and epidemiological characterization of Streptococcus uberis isolated from bovine mastitis using conventional methods. J. Vet. Sci. 4:213-223.

Lapornik, B., M. Prosek, A. G. Wondra. 2005. Comparison of extracts prepared from plant by-products using different solvents and extraction time. Journal of Food Engineering. 7: $214-222$.

Myllys, V. and Rautala, H. (1995); Characterization of clinical mastitis in primiparous heifers. J. dairy Sci. 78: 538-545.

Nshimo C.M., J.M. Pezzuto, A.D. Kinghorn and N.R. Farnsworth. 1993. Cytotoxic Constituents of Muntingia calabura Leaves and Stems Collected in Thailand. Int. J. Pharmacol. 31: 77-81.

Ody, P. 1993. The complete medical herbal. New York, Dorling Kindersley Limited, pp: 132-171.

Palombo E.A and S.J. Semple. 2001. Antibacterial Activity of Traditional Australian Medicinal Plants. J. Ethnopharmacol. 77: 151-157. 
Peschel, W., F. Sanchez-Rabaneda, W. Dn, A. Plescher, I. Gartzia, D. Jimenez, R. LamuelaRaventos, S. Buxaderas, and C. Condina. 2006. An industrial approach in the search of natural antioxidants from vegetable and fruit wastes. Food Chem. 97: 137-150.

Portillo A, R., R. Vila, B. Freixa, T. Adzet, and S. Cañigueral. 2001. Antifungal Activity of Paraguayan Plants Used in Traditional Medicine. J. Ethnopharmacol. 76: 93-98.

Rabe $\mathrm{T}$ and J. Van Staden. 2000. Isolation of An Antibacterial Sesquiterpenoid from Warburgia salutaris. J. Ethnopharmacol. 73: 171-174.

Sarac N and A. Ugur. 2007. Antimicrobial Activities and Usage in Folkloric Medicine of Some Lamiaceae Species Growing in Mugla, Turkey. EurAsian J. BioSci. 1(4): 28-34.

The Merck Index. 2001. An encyclopedia of chemicals,drugs and biological, $13^{\text {th }}$ edition.

Tiwari, P.,B. Kumar, M. Kaur, G. Kaur, and H. Kaur. 2011. Int. Pharm. Sciencia, 1, 98-106. Zakaria, Z. A., H. Zaiton, E.F.P. Henie, A.M. Mat Jais, D. Kasthuri, M. Thenamutha, F. W. Othman, R. Nazaratulmawarina and C. A. Fatimah. 2006. Journal of Pharmacology and Toxiology. 8: 480-486. 